Nicola Phillips ${ }^{1}$

\title{
The Limits of 'Securitization': Power, Politics and Process in US Foreign Economic Policy
}

CONTEMPORARY DEVELOPMENTS IN WORLD POLITICS APPEAR TO HAVE created an unusually propitious environment for academic fads. The particular orientation of the George W. Bush administration in the United States and the impact of the events of 11 September 2001 have generated a widespread anxiety to proclaim 'newness' - to understand what is seen to be a fundamentally 'new' world order with a 'new' form and deployment of US power within it. In this light, such new or reshaped concepts as pre-emption, unilateralism, terrorism, security and, most of all, empire and imperialism have spawned a literature that is already huge. The assertion of 'newness' has also imbued a set of emerging contentions about political economy, which can be summarized in the argument that the economic engagement of the USA in the world is marked by a process of 'securitization', in which foreign economic policy, particularly trade policy, is deemed to be hijacked and fundamentally reordered by overarching security-related priorities and interests. It is scrutinizing and, ultimately, rejecting this latter contention that is my aim in this paper. I contend that such an approach fundamentally misrepresents the substance of contemporary US foreign economic policy, the political environment in which it is articulated and the process by which it is made.

It is important to be clear from the outset that my argument is emphatically not that a nexus between economic and security policy

${ }^{1}$ I am grateful to the participants of the conference on 'Asia Pacific Economies: Multilateral vs. Bilateral Relationships' at the City University of Hong Kong in May 2004 for their early reactions to the first draft of this paper. Wyn Grant, Jennifer Jeffs and Tony Payne provided constructive and challenging comments at various stages, and I am indebted to two anonymous referees for their helpful reports. Remaining insufficiencies are fully my responsibility. 
does not exist or is not important; rather, it has always existed and has always been made explicit, both by US state and government actors in the articulation of their strategies and by scholars in wide-ranging theoretical and empirical investigation. Nor is it my contention that there is nothing new about the ways in which that nexus has been articulated by the Bush administration in a post $-9 / 11$ context. Rather, my central arguments here are three-fold. First, I suggest that, in the same manner as in previous periods and under previous administrations, the economic-security nexus has taken a distinctive form dictated by the particular nature and the extent of security concerns at a given time, the condition of global and regional economic processes and, to an extent, the particular inclinations of different administrations. Secondly, I argue that there is far more continuity in the contours of trade and foreign economic policy and the processes by which they are made than a thesis of securitization and its attendant propositions permit us to recognize. Thirdly, I contend that a securitization approach suggests a degree of systematic strategic design and coherence that has never been, and is not, characteristic of the US foreign economic policy-making process.

In order to put forward a fuller account and explanation of the evolution of contemporary foreign economic strategies, the second part of the paper addresses three key issues that, I suggest, are obscured by an emphasis on securitization. These three issues, which must be placed together with the central issue of the economic-security nexus, are (a) the form of 'ad hoc reactivism', to use Richard Feinberg's apposite formulation, ${ }^{2}$ which has always pervaded trade policy-making in the US and remains the hallmark of contemporary trade strategies; (b) a set of commercial and, moreover, wider economic goals designed to entrench the interests of US investors at the heart of a neo-liberal economic order; and (c) a set of goals associated with competition for regional leadership, particularly in Asia-Pacific and the Americas, which cannot meaningfully be subsumed into notions of 'security'. A further factor, which permeates all of these considerations, concerns the range of political, institutional and electoral forces that shape foreign economic policy and the process by which it is made. These reveal (and permit) little in the way of the significant alteration of the

${ }^{2}$ Richard E. Feinberg, 'The Political Economy of United States' Free Trade Arrangements', The World Economy, 26 : 7 (2003), pp. 1019-40. 
'normal' politics and processes of policy-making that is posited by the thesis of securitization.

\section{THE EVOLUTION OF US FOREIGN ECONOMIC POLICY}

Throughout the post-war period, the international engagement of the USA was marked by a distinctive and largely exclusive preference for multilateralism. In trade, successive administrations consistently eschewed other modes of negotiating the construction of a (neo-) liberal world order, most obviously those regionalist strategies spearheaded by the European Union (EU). Bilateralist streaks, while evident in post-war trade strategies, were limited to a collection of policy instruments that were deployed in bilateral trade relationshipssuch as voluntary export restraints (VERs) and trade remedies like Section 301 and later Super 301, along with bilateral arrangements in single-issue areas such as intellectual property - rather than constituting encompassing bilateral trade agreements. Global economic liberalization, for the USA, remained encapsulated within a strong preference for the multilateral, rather than regional or bilateral, negotiating arena. At the same time, the historically close links between US economic strategies and multilateralism have consistently been characterized by a fundamental ambivalence in state and public attitudes to multilateral institutions and the rules these institutions have established, even though these rules have been developed largely under US impetus. ${ }^{3}$ While the USA has exercised structural dominance within the institutions of the world trading system, as in the international financial organizations, nevertheless its record of compliance with multilateral trade rules and procedures has been an increasingly unhappy one, particularly since the 1980s. ${ }^{4}$ As the dynamism and effectiveness of multilateral trade negotiations have also declined, especially since the conclusion of the Uruguay Round in 1994, so US frustration with their ponderous and leadenfooted progress has increased. At the same time, the USA's political

${ }^{3}$ Edward C. Luck, Mixed Messages: American Politics and International Organization, 1919-1999, Washington, DC, Brookings Institution Press, 1999.

${ }^{4}$ Diana Tussie, 'Multilateralism Revisited in a Globalizing World Economy', Mershon International Studies Review, 42 (1998), pp. 183-93; C. Fred Bergsten, 'A Renaissance for U.S. Trade Policy?', Foreign Affairs, 81: 6 (2002), pp. 86-98. 
dominance of the process has been complicated by increasingly fractious relations with both the EU and developing countries. ${ }^{5}$ The result of these trends has been a much greater inclination on the part of successive US governments to explore alternative avenues and arenas for advancing global trade liberalization.

The turn to regionalism in the late 1980s and early 1990s - with the North American Free Trade Agreement (NAFTA), the Enterprise for the Americas Initiative (EAI) which gave rise to the Free Trade Area of the Americas (FTAA) project, the Asia-Pacific Economic Cooperation (APEC) forum and the ASEAN Regional Forum (ARF) - must, in this sense, be understood as arising from a growing disaffection in the USA with the progress of multilateral negotiations and, moreover, the growing political problems encountered in realizing the particular vision of a multilateral trading order that animated US engagement in it. It was also a product of two other preoccupations. The first was that associated with perceptions within the USA of a steady erosion of its global hegemony. The 'declinist' debates became prevalent from the 1970s onwards, and were epitomized by anxious concern about the apparently superior growth performances of Japanese and German models of capitalism and, in particular, the associated 'threat' to the USA emanating from the Japanese economy. The question of whether this was a process of actual hegemonic decline, ${ }^{6}$ a more conjunctural set of perceptions of it that proved ultimately to be unfounded ${ }^{7}$ or in fact a more specious and instrumental claim that served to justify the retraction of commitment to multilateral institutions $^{8}$ is, for present purposes, secondary to the point that regionalism became incorporated into the global hegemonic strategies of the

${ }^{5}$ See J. Michael Finger and Julio J. Nogués, 'The Unbalanced Uruguay Round Outcome: The New Areas in Future WTO Negotiations', The World Economy, 25: 3 (2002), pp. 321-40; Arvind Panagariya, 'Developing Countries at Doha: A Political Economy Analysis', The World Economy, 25: 9 (2002), pp. 1205-33. Amrita Narlikar, International Trade and Developing Countries: Bargaining Coalitions in the GATT and WTO, London, Routledge, 2003.

${ }^{6}$ Anthony Payne, 'The United States and its Enterprise for the Americas', in Andrew Gamble and Anthony Payne (eds), Regionalism and World Order, Basingstoke, Macmillan, 1996, pp. 93-129.

${ }^{7}$ Michael Cox, 'Whatever Happened to American Decline? International Relations and the New United States Hegemony', New Political Economy, 6: 3 (2001), pp. 311-40.

${ }^{8}$ Susan Strange, 'The Persistent Myth of Lost Hegemony', International Organization, 41: 4 (1987), pp. 551-74. 
USA largely as an attempt to counter the perceived threats to its economic dominance emerging from other regions and other powerful economies.

The second and related preoccupation was one that achieved particular salience towards the end of the 1990s, and is still deployed frequently in speeches by trade policy makers and others as grist to the new regionalist and bilateralist mill - namely, that in the negotiation of regional and bilateral trade agreements the USA has consistently been, and remains, behind the curve. Echoed widely in political discourse, public commentary and congressional hearings on the matter, ${ }^{9}$ Robert B. Zoellick, the United States Trade Representative (USTR) during the first administration of George W. Bush, frequently observed that the USA was 'falling behind' the rest of the world and, moreover, its major competitors and partners:

... While the United States stepped aside, others moved ahead. The European Union now has 27 bilateral free trade and customs agreements, 20 of which it negotiated in the course of the 1990s, and the EU is in the process of negotiating 15 more. After NAFTA, Mexico sped past the United States to negotiate eight free trade agreements with 32 countries. Even Japan has been working on a free trade agreement with Singapore and is exploring options with Canada, Mexico, Korea and Chile. There are over 130 free trade agreements in the world; the United States is party to only two. There are 30 free trade agreements in the Western hemisphere; the United States belongs to only one. ${ }^{10}$

The call was thus for 'prompt action' and favourable legislative disposition in order to 'clear the way for America's international trade leadership and economic interests'. ${ }^{11}$ The thinking resulting from this conjunction of concerns does not signify a retraction of a ceteris paribus preference for multilateral trade negotiations. But what it does indicate is that, since the late 1980s, there has been a sustained expansion of the armoury of trade policy instruments and the arenas in which trade liberalization is negotiated. The Bush administration's trade policy has thus represented a continuation,

${ }^{9}$ US House of Representatives, Committee on Ways and Means, transcript, 'Free Trade Deals: Is the United States Losing Ground as its Trade Partners Move Ahead?, Hearing Before the Subcommittee on Trade of the House Committee on Ways and Means', 107th Congress, first session, 29 March 2001.

${ }^{10}$ Robert B. Zoellick, 'American Trade Leadership: What is at Stake?', speech to the Institute for International Economics, Washington, DC, 24 September 2001.

${ }^{11}$ Robert B. Zoellick, 'Falling Behind on Free Trade', New York Times, 14 April 2002. 
extension and acceleration of many longer-term trends in US foreign economic strategies.

This said, from 2000 onwards the strategy of negotiation on 'multiple fronts' was elevated to the status of policy 'credo' by the USTR, ${ }^{12}$ and this was itself facilitated by key changes in the political climate surrounding trade policy. The unavailability to the Clinton administration of so-called 'fast-track' negotiating authority, after it expired in 1994 and its renewal was refused by Congress in 1998, was crucial to the relatively scant number of trade agreements negotiated over the 1990s, and indeed to the overall lack of defining political leadership that was characteristic of most of the ongoing trade projects in which the USA was involved, notably the FTAA process. This absence of institutional and legislative hoists to the trade negotiations process was redressed early in the Bush administration in the granting, under the Trade Act of 2002, of what by then had been re-named Trade Promotion Authority (TPA). In this incarnation, however, TPA was marked by an increase in congressional input and powers of scrutiny, and as such by an enhancement of historically substantial congressional involvement in the trade policy-making process. At the same time, it contained a raft of concessions to 'sensitive' domestic economic interests, such that protectionist pressures were firmly embedded in the substance of trade negotiations. Inasmuch as TPA sets the parameters for US trade negotiators, from the outset the negotiating terrain is thus structurally skewed towards US interests and the framework for the negotiations is infused with distinctively US policy priorities. ${ }^{13}$ Yet TPA did facilitate the resumption of aggressive dynamism in US trade policy that had been lacking under the preceding Clinton administration.

This, then, was the context within which the credo of achieving a 'competition in liberalization' was elaborated. This connoted an advance towards the negotiation of trade agreements on 'multiple fronts' - multilateral, regional and bilateral - designed to place the USA 'at the center of a network of initiatives'. ${ }^{14}$ The rationale was that such a strategy "provides leverage for openness in all negotiations,

${ }^{12}$ Robert B. Zoellick, ‘Our Credo: Free Trade and Competition’, Wall Street Journal, 10 July 2003.

${ }^{13}$ For a fuller elaboration of this argument, see Nicola Phillips, 'US Power and the Politics of Economic Governance in the Americas', Latin American Politics and Society, 44: 4 (2005), pp. 1-25.

${ }^{14}$ Zoellick, 'American Trade Leadership'. 
establishes models of success that can be used on many fronts, and develops a fresh political dynamic that puts free trade on the offensive'. ${ }^{15}$ The element of 'competition' relates to the attempt to create a series of precedents with which, in each successive trade agreement, the baseline requirements for subsequent agreements are ratcheted up, along with the incentives for trading partners to negotiate with the USA distinctively on its terms. The trade policy credo, in other words, accelerates the momentum of global liberalization by increasing the incentives for countries to negotiate bilateral trade agreements with the USA, designed sequentially to raise the bar for subsequent negotiations. ${ }^{16}$ Given that, as we will see in detail later, the selection of countries for these negotiations is primarily reactive in nature - it is the country (or group of countries) aspiring to a trade agreement with the USA which is required, in the first instance, to make its case for consideration - the expectation among US trade policy makers is that a competition among countries will consequently emerge to provide the most attractive set of incentives for the initiation of negotiations. By extension, as the dynamism in world trade shifts to bilateral negotiations, it is a distinctively US trade agenda that is thereby facilitated as the foundation for this new playing field.

The manner in which this strategy has evolved and been deployed has been conditioned by key shifts in multilateral and regional trade politics. Most notable among these have been the gradual implosion of World Trade Organization (WTO) negotiations and the disintegration of the FTAA project in late 2003. As a result of the overriding concern with how then to establish and exercise 'leverage' in its trade negotiations and economic relationships, ${ }^{17}$ the USTR has afforded even greater priority to bilateral negotiations. With rhetoric reminiscent of that surrounding the invasion of Iraq - leading one observer

${ }^{15}$ Office of the United States Trade Representative, 2003 Annual Report and 2004 Trade Policy Agenda of the President of the United States on the Trade Agreements Program, Washington, DC, USTR, 2004, p. 1.

${ }^{16}$ For a discussion of the use of precedents, see Craig VanGrasstek, 'US Plans for a New WTO Round: Negotiating More Agreements with Less Authority', The World Economy, 23: 5 (2000), pp. 673-700.

17 The issue of 'leverage' and mechanisms for achieving it permeated my extensive discussions and interviews about foreign economic policy with US government officials, representatives of congressional offices and committees, trade policy makers, representatives of key state agencies, representatives of business and labour 
pithily to cast Zoellick as a 'Donald Rumsfeld of trade policy'18 - the strategy has been to construct a 'coalition of the liberalizers': to pursue bilateral agreements with 'willing' countries, concomitantly to exclude and isolate the 'unwilling', and thereby to exert sustained pressure on 'recalcitrant' countries such as Brazil and India. Thus, in the FTAA context, Zoellick declared in 2002 that 'we want to negotiate with all the democracies of the Americas through the FTAA, but we are also prepared to move step-by-step towards free trade if others turn back or simply are not ready'. ${ }^{19}$ Precisely this occurred when the clash between Brazilian and US positions were deemed to have generated stalemate in late 2003. In the multilateral context, again in response to the Brazilian-led G-20+ coalition of developing countries formed at the 2003 WTO ministerial in Cancún, Zoellick declared his government's determination not to entertain or wait for the 'won't do' countries in the multilateral system and to undermine the G-20+ by 'mov[ing] towards free trade with can-do countries'. ${ }^{20}$ The coalition splintered rapidly as the prospect of trade negotiations with the USA was held out as an incentive not to participate in this grouping, particularly for smaller countries.

The cumulative result has been a rash of bilateral negotiations and agreements, a number of which were signed soon after TPA was granted and a greater number of which were set in train following the collapse of the Cancún meetings and the original ambition for an FTAA. In the Americas, for example, agreements with Chile and six Central American countries (the latter to form a Central American Free Trade Area (CAFTA)), were ratified by the US Congress in July 2003 and July 2005 respectively. ${ }^{21}$ In April 2004, multiparty negotiations for Trade Promotion Agreements with a number of Andean

organizations, and others. All interviews cited in this paper were conducted in Washington DC during September and October 2004, and all were conducted on a 'not for attribution' basis.

18 Jagdish Bhagwati, 'Don’t Cry for Cancún', Foreign Affairs, 83: 1 (2004), p. 52.

${ }^{19}$ Robert B. Zoellick, 'Trading in Freedom: The New Endeavour of the Americas', Economic Perspectives: An Electronic Journal of the U.S. Department of State, 7: 3 (2002), available at http://usinfo.state.gov/pub/ejournalusa/economic_perspectives.html.

${ }^{20}$ Robert B. Zoellick, 'America Will not Wait for the Won't-Do Countries', Financial Times, 22 September 2003.

${ }^{21}$ At the end of 2006, the CAFTA agreement had been ratified by six of the seven participating countries, with the exception of Costa Rica. The agreement entered into force with El Salvador in March 2006 and with Honduras and Nicaragua in April 2006. 
countries were initiated, and Panama followed suit. ${ }^{22}$ In Asia-Pacific, bilateral free trade agreements were signed with Singapore (May 2003) and Australia (May 2004); plans for agreements with ASEAN countries were set out in the form of the USA's Enterprise for ASEAN Initiative; and negotiations were set in train with South Korea and Malaysia in early 2006. Elsewhere, bilateral agreements were concluded with Jordan in 2001, with Morocco, Bahrain and the five member countries of the Southern African Customs Union (SACU) in 2004, and with Oman in 2006. The prospect of a Middle East Free Trade Area (MEFTA) was advanced in mid-2003. At the same time, the US government has signed a range of the Trade and Investment Framework Agreements (TIFAs) with such countries as Thailand, Brunei, Kuwait, Saudi Arabia, the Philippines, Indonesia and Afghanistan, and has continued its long-standing prioritization of Bilateral Investment Treaties (BITs) in agreements with such countries as Uruguay.

It should, of course, be noted that bilateralism is not new, in the USA or elsewhere, and indeed is neither original nor unique to the USA. This much should be obvious from the statements cited earlier lamenting the proliferation of agreements that left the USA falling behind its competitors. US bilateralism was a late response to a much more widespread trend. Japan, Chile, Mexico, the EU and Canada are salient examples, along with a great many others, of countries and regions engaged in a long-standing and continuing pursuit of a wide variety of bilateral negotiating strategies. ${ }^{23}$ Yet what is new in the USA is the pace at which such agreements have been negotiated and, indeed, the political ease with which the USTR has been able both to attract negotiating partners and successfully conclude negotiations. Each of the bilateral agreements noted above has departed only insubstantially, if at all, from the schedule of demands that US negotiators would have brought to the first negotiating session, and many have been negotiated in a period of only a few months.

${ }^{22}$ Negotiations were concluded with Peru in December 2005 and Colombia in February 2006, and the agreements were signed respectively in April 2006 and November 2006. Ecuador was also part of these negotiations for an Andean Trade Promotion Agreement.

${ }^{23}$ For discussions of bilateralism in the Asia-Pacific and the Americas, see John Ravenhill, 'The New Bilateralism in the Asia-Pacific', Third World Quarterly, 24: 3 (2003), pp. 299-318; Barry Desker, 'In Defence of FTAs: From Purity to Pragmatism in East Asia', Pacific Review, 17: 1 (2004), pp. 3-26; Phillips, 'US Power'.

(C) The Author 2007. Journal compilation (C 2007 Government and Opposition Ltd 
What explains the evolution of US trade strategies in these directions? As outlined earlier, a full explanation of the evolution of US foreign economic strategies requires attention to a range of factors: the economic-security nexus; the ad hoc and reactive nature of the policy-making process; a set of commercial and economic interests; the circumvention of regional leadership (in Asia-Pacific and the Americas); and, infusing all of these other factors, the domestic politics surrounding the policy process. It is to these that we now turn our attention.

\section{THE ECONOMIC-SECURITY NEXUS}

In the commendable and necessary efforts to explain the shifts in US engagement in the world that have occurred under the Bush administration, there has been a marked tendency to perceive 'security' as the dominant concern driving this engagement, and as representing an overarching force that brings together all other policy areas for its purposes. This proposition has been extended to the realms of both globalization and foreign economic policy, notably with the application of the notion of securitization developed by Barry Buzan, Ole Wæver and Jaap de Wilde. ${ }^{24}$ They define a case of securitization as occurring when 'a securitizing actor uses a rhetoric of existential threat, and thereby takes an issue out of what under those conditions is "normal politics"' . In other words, 'if by means of an argument about the priority and urgency of an existential threat the securitizing actor has managed to break free of procedures or rules by which he or she would otherwise be bound, we are witnessing a case of securitization' ${ }^{25}$ Securitization, in this sense, is not only about the deployment of the rhetorical device of 'security' and the location of policy discourse within that framework, but also about the capacity thereby to achieve a disruption to the normal rules, practices and politics of policy-making.

Taken to the sphere of foreign economic policy, securitization has thus been formulated as a process by which 'the securitising actors. ... have sought to treat economic policy in a manner different to

${ }^{24}$ Barry Buzan, Ole Wæver and Jaap de Wilde, Security: A New Framework for Analysis, Boulder, CO, Lynne Rienner, 1998.

${ }^{25}$ Ibid., pp. 24, 25.

(C) The Author 2007. Journal compilation (c) 2007 Government and Opposition Ltd 
the normal rules and practices of economic policy making and implementation' ${ }^{26}$ The resulting framing of globalization and foreign economic policy as national security issues, the linking of economic policy to overarching security objectives and the political legitimization of policy initiatives on that basis are considered to be the hallmarks of the contemporary foreign economic engagement of the USA. Both globalization and US foreign economic policy (although the two terms are often, problematically, used interchangeably) are thus understood to have become, in essence, security issues and avenues by which a securitization of the world order is pursued by US governments. While it is readily conceded in these analyses that a nexus between economic and security policies was evident before $9 / 11$, nevertheless it is the central positing of a correlation between the degree of global military dominance exercised by the USA, the extent of the 'new' unilateralist inclination and the deployment of economic policy as 'an arm of security policy ${ }^{27}$ that is directly consistent with the argument that the post- $9 / 11$ world is qualitatively distinctive in the extent of this capturing of economic policy by the exigencies of security strategies.

Let us then consider the first assumption of this approach, namely, that foreign economic policy is shaped by an overarching set of security-related priorities and, indeed, 'sold' politically on that basis. The most immediate question that presents itself is very simple: when has it ever been the case that economic and security concerns have not been intrinsically linked in the core foreign and foreign economic policies of the USA? Indeed, academic work spanning several decades has sought, in various ways, to understand, theorize and demonstrate empirically that linkage, perhaps the most visible contributions being those that have focused on the relationship between economic interdependence and conflict and the question of whether a version of the 'democratic peace' hypothesis can explain trading patterns in various historical periods. ${ }^{28}$ At

${ }^{26}$ Richard Higgott, 'American Unilateralism, Foreign Economic Policy and the "Securitization" of Globalisation', CSGR Working Paper 124/03, University of Warwick, September 2003, p. 4; also see Desker, 'In Defence of FTAs', p. 19.

${ }^{27}$ Higgott, 'American Unilateralism', p. 8.

${ }^{28}$ Examples of prominent interventions in a diverse debate include, among many others, Joanne Gowa, Allies, Adversaries and International Trade, Princeton, NJ, Princeton University Press, 1994; Joanne Gowa, 'Bilpolarity, Multipolarity, and Free Trade', American Political Science Review, 83: 4 (1989), pp. 1245-56; Edward D. Mansfield and 
the same time, the 'normal rules and practices' of both foreign and foreign economic policy-making have always been premised explicitly on the linkage between economic and security interests, both rhetorically and in practice, and as much during the post-war, Cold War period as later during the administrations of George H. W. Bush, Bill Clinton and George W. Bush, not to mention during much earlier eras of nationalist mercantilism. One could marshal several papers' worth of empirical evidence on this point, but here it is sufficient simply to point to the Marshall Plan and the post-war reconstruction of Europe, several decades of aid policy, the deployment of economic sanctions and embargoes during the Cold War, the economic leverage brought to bear against countries such as Chile under socialist president Salvador Allende in the early 1970s, the history of Cold War economic relations with China and the Soviet Union, the evolution of foreign policy towards key oilproducing regions and countries, the founding rationale of the post-war international trading and financial orders - and so on. A range of these strategies were indeed aimed at rebuilding allies and reconstructing states that had formerly been military rivals in the context of a bipolar security divide, but this cannot be taken to indicate a clear separation of economic and security policy arising from the fact that the major security rival (the USSR) was not the major economic rival of the USA: ${ }^{29}$ on the contrary, the economicsecurity nexus lay at the heart of the wider battle to contain and defeat communism in its various arenas and manifestations.

With the end of the Cold War, and especially under the Clinton administration, the discourse and politics of globalization generated perceptions that the traditional Cold War-inspired balance between 'high' and 'low' politics had tipped towards the latter. Susan Strange was one of many arguing around this time that the primary form of competition in world politics was now for global market shares rather

Jon C. Pevehouse, 'Trade Blocs, Trade Flows, and International Conflict', International Organization, 54: 4 (2000), pp. 775-808; Edward D. Mansfield, Power, Trade, and War, Princeton, NJ, Princeton University Press, 1994; Mark Gasiorowski, 'Economic Interdependence and International Conflict: Some Cross-National Evidence', International Studies Quarterly, 30: 1 (1986), pp. 23-38; and Barry Buzan, 'Economic Structure and International Security: The Limits of the Liberal Case', International Organization, 38: 4 (1984), pp. 597-624.

${ }^{29}$ Higgott, 'American Unilateralism', pp. 7-8. 
than territory or military primacy. ${ }^{30}$ To an extent, this was undoubtedly the case. But it was so not because of a 'de-linking' of economic and security strategies. What was different about the 1990s was the absence, for the first time since the end of the Second World War, of an immediate and overarching security threat. Cold War economic policies were very directly part of an integrated package of anticommunist strategies deployed by the USA, and rhetorically were validated and facilitated by the invocation of this threat. As this immediate threat receded and gave way to a focus on economic competition between the USA and rival forms of capitalism elsewhere, the dynamics of the economic-security linkage took a form that was perhaps more muted but nevertheless oriented very clearly towards the same sort of integration of economic and security policies that was in evidence in the Cold War anti-communist purpose.

What was also different during the 1990s was the nature (as opposed to the immediacy) of perceived security threats. 'Nontraditional' threats received considerably more attention than they had previously from policy makers preoccupied with the bipolar ideological conflict and the management of détente. In the 1990s, in other words, the security agenda that occupied the White House, the State Department and other key agencies shifted to encompass a range of threats which were not new per se, but rather were longstanding security issues that had simply been accorded less priority during the Cold War or been formulated in a different manner in this context. The associated policy shifts came to include a much less equivocal agenda for global democratization, the management of a range of environmental threats, the prioritization of humanitarian and peace-keeping operations as opposed to direct military intervention, the control of illegal and illicit flows of people and goods, and so on. (Energy, of course, occupied similar positions of salience in both periods.) The point is that economic and trade strategies were designed in a manner very clearly consistent with the range of key security interests identified by the various agencies of the US government and state during the 1990s, even though these interests were not primarily of the military variety that predominated during the Cold War and indeed have risen again to salience under the George

${ }^{30}$ Strange, 'The Persistent Myth'; John Stopford and Susan Strange, Rival States, Rival Firms: Competition for World Market Shares, Cambridge, Cambridge University Press, 1991. 
W. Bush administration. Moreover, foreign economic policy was a primary vehicle by which these security concerns were addressed, and vice versa.

The Americas is a fertile region for illustrative examples. US interest in the NAFTA corresponded at least as much with goals associated with political democratization in Mexico as they did with trade and investment-related considerations; it also corresponded with a range of border security concerns such as migration and drug trafficking. The Andean Trade Preferences Act (ATPA) of 1991, likewise, was articulated as a vehicle through which to 'help' Andean countries tackle the problem of the drug trade. The Caribbean Basin Initiative (CBI) of 1984 was very explicitly a part of US Cold War security strategies in that region, being introduced early in the Reagan administration as an intended remedy to the 'sea of splashing dominoes' that the Caribbean Basin was deemed to have become. The evolution of the CBI into the 1990s was heavily marked by the conditioning of continued economic and trade benefits under its auspices on cooperation with aggressive US drug control strategies and, to a lesser extent, those associated with the control of illegal migration. The deployment by the Clinton administration of economic policy primarily for broader 'diplomatic' and political/democratization goals seen as 'economic diplomacy at its best' ${ }^{31}$ - was also evident in the Africa and China trade bills that it successfully passed and the closer economic engagement with Vietnam that it set in train. The Clinton government, indeed, frequently invoked a notion of 'linkage politics' as the hallmark of its strategies of global engagement.

Yet what was clearly distinctive about the Clinton administration was the strikingly low profile that trade occupied on the political and policy-making agendas. An important part of the explanation for this lies in the growing 'stalemate over globalization' ${ }^{32}$ that characterized domestic political debates in the USA and fostered sceptical congressional and public opinion on the virtues of free trade. Another part of the explanation for the stalemate resides in the absence of fasttrack negotiating authority, but this is a circular argument inasmuch as this absence was itself part of the low profile afforded to trade and consequently also stands in need of explanation. The same could be said of the third possible explanation, which revolves around the

${ }^{31}$ David E. Sanger, 'A Grand Trade Bargain', Foreign Affairs, 80: 1 (2001), p. 67.

${ }^{32}$ Bergsten, 'A Renaissance for U.S. Trade Policy?'. 
intrinsically fragmented nature of the US state and the consequent difficulty to which the formulation and implementation of trade policy has always been subject. The traditional tension between the priorities of the various agencies associated with trade policy-making - the Department of State being concerned primarily with overarching diplomatic and strategic goals, Commerce with the interests of specific industries, Treasury with macroeconomic issues, and so on ${ }^{33}$ - was particularly pronounced during the Clinton administration. Indeed, the inter-agency process through which trade policy is made ${ }^{34}$ along with the substantial congressional oversight and input functions developed in successive reforms since the middle of the twentieth century, have consistently made the US trade policy process a strikingly unwieldy, diffuse and politically delicate one. But while this constitutes another partial answer to the low profile of trade on the agenda, it also invites the question of why these tensions should have hampered effective policy-making more during the 1990s than at previous times or subsequently.

I suggest that what the Clinton administration lacked was the rallying call provided by an immediate and overarching security threat, and this has implications for the ways that we assess the economic-security nexus - and indeed the securitization thesis under the George W. Bush administration. This is not a question of the intrinsic salience of trade or economic relationships, which, as noted, became central with the decline of Cold War-inspired foreign

${ }^{33}$ For discussions, see, for example, Stephen D. Cohen, The Making of United States International Economic Policy: Principles, Problems and Proposals for Reform, Westport, CT, Praeger, 2000; I. M. Destler, American Trade Politics, Washington, DC, Institute for International Economics, 1995; and Tony Porter, 'The United States in International Trade Politics: Liberal Leader or Heavy-Handed Hegemon?', in Dominic Kelly and Wyn Grant (eds), The Politics of International Trade: Actors, Issues, Regions, Basingstoke, Palgrave, 2005, pp. 204-20.

${ }^{34}$ The inter-agency process incorporates a wide range of state agencies, most obviously the Office of the USTR and the Departments of State, Treasury, Commerce, Agriculture and Labor, but including many Departments such as, among others, Interior, Energy, Health and Human Service, Justice and Transportation, the Central Intelligence Agency, National Security Council, National Economic Council, Environmental Protection Agency and the Office of Management and Budget. For a good overview, see Jon E. Huenemann, 'On the Trade Policy-Making Process in the United States', in Inter-American Development Bank, 'The Trade Policy-Making Process: Level One of the Two Level Game: Country Studies in the Western Hemisphere', INTAL-ITD-STA Occasional Paper 13, March 2002, pp. 67-73.

(C) The Author 2007. Journal compilation (C) 2007 Government and Opposition Ltd 
policy and the acceleration of globalization. Rather, it is a question about the legislative and political environment in which foreign economic policy is made. The re-emergence of an immediate and pressing threat in the form of global terrorism provided again a suitable rhetorical weapon for policy makers to mitigate some of the aggressive partisanship that had plagued trade policy since the 1980s, and thus achieve the legislative environment that allowed for the elaboration of more dynamic and wide-ranging trade policies. It is certainly the case that $9 / 11$ played an important part in securing the passage of TPA in 2002: until that time the political environment was sufficiently fraught for most observers to be sceptical about its prospects.

The argument that presents itself, then, is that for a time the re-appearance of an immediate security threat under the Bush administration acted in ways similar to previous periods of high security 'alert' in Washington to mitigate somewhat the divisions between state agencies on matters of trade and foreign economic policy, and indeed to foster a bipartisan approach to those policy issues identified as relating to key national security interests. In such periods, in addition, the Executive branch characteristically assumes the loudest voice in matters of policy formulation, and in this case its inclination to tie trade strategies very concretely into the management of the security threat tended to hold sway over the more parochial interests of Commerce, Treasury and other departments. Likewise, despite the secular trend towards a removal of trade policy from the formal remit of the State Department, the latter's influence remains important, through the channels of the inter-agency process and through its salience in particular periods of high security threat. ${ }^{35}$ Thus linkage politics achieved a particular type of expression under the Bush administration after 9/11 that was encapsulated in a somewhat more propitious political and legislative environment for trade than that which prevailed for much of the 1990s.

Yet, on closer examination, the notion of securitization does not capture this dynamic particularly well. In one sense, it seems to me that the very most that we can say about the Bush administration is that there has been a process of what, clumsily, we could call a 'terrorism-ization' of foreign economic policy, as the rhetoric of the war on terror became important to the tactics of political persuasion

${ }^{35}$ Interviews, officials in the US Department of State. 
deployed by trade policy makers. Thus, for Zoellick, the international market economy and global trade were a fundamental 'antidote to this violent rejectionism' ${ }^{36}$ It is not security per se that has achieved a salience sufficient to warrant suggestions of the securitization of foreign economic policy, but rather a particular version of the economic-security nexus that has come to focus on the overarching threat of terrorism. In other words, it is the nature of the security agenda that is different and 'new' in the post-9/11 period; the emphasis on security in US foreign and foreign economic policies, and the tight linkage between economic and security strategies, is not.

More importantly, the notion of a sudden but fundamental change, suggested by the correlation between the extent of unilateral military dominance and the extent to which economic policy is subordinated to or hijacked by security policy, appears even at this early juncture to have been over-stated. Clearly the arguments advanced by many globalization theorists about the primacy of economic relations and the disappearance of security from the core of world politics had ultimately a limited shelf-life. Yet, even so, the rhetorical utility of overarching threat also declined very quickly, and indeed was, at best, slight in the first place. The 2002 Trade Act was secured by the slimmest margin of three votes, and thus constitutes only the flimsiest of grounds for a general argument observing a shift to greater bipartisanship as a result of the security threat. Equally, in the years since $9 / 11$, the initial drive to demonstrate consensus and unity across the agencies of state and across the branches of government has fragmented and in some cases disintegrated, and it is by no means clear in general that the war on terror carries that unifying weight that it brought to bear on US politics in the immediate aftermath of the terrorist attacks. Moreover, certainly in the realms of the trade process, there is no evidence that the framing of foreign economic policy as a national security issue led in any significant measure to a shift in the 'normal' politics and processes - and indeed the marked partisanship - that have historically been characteristic of this policy area. The Bush administration entered its second term with its foreign economic agenda facing extremely difficult political

${ }^{36}$ Robert B. Zoellick, 'The WTO and New Global Trade Negotiations: What's at Stake?', speech to the Council on Foreign Relations, Washington, DC, 30 October 2001. 
circumstances, within Congress, among business and labour interests, and indeed in public attitudes to trade.

\section{Processes and Politics of Trade Policy-Making}

We have seen that an instance of 'securitization' is identified by a legitimized disruption to the normal rules and practices of the policymaking process. Yet, in the basic terms of the process itself, the customary routes by which foreign economic policy is made have not been altered by any invocation of urgency associated with a linking of economic and security issues; moreover, there has been no attempt to circumvent these processes. The inter-agency process remains intact and functioning, and has never been suspended; indeed, it was expanded on the recommendations of the National Security Council in May 2003 in order to improve the process of selecting trade partners. ${ }^{37}$ Likewise, congressional scrutiny of trade policy has been enhanced rather than diminished under the Bush administration, and those powers have consistently been exercised fully.

In terms of the politics of foreign economic policy, again it is difficult to assemble any robust evidence demonstrating a mitigation, through the invocation of relevance to national security, of what would be considered the 'normal' public and congressional politics surrounding trade. At the start of the second Bush administration, in the words of Senator Charles E. Grassley (R-Iowa), 'trade is more controversial than it has been for some time'. ${ }^{38}$ Moreover, there has been a striking decline in public support for trade since the start of the decade. The primary reasons for this decline are uniformly cited as the emerging 'threat' from the Chinese economy and the experience of the NAFTA. ${ }^{39}$ Undoubtedly the announcement in early 2006 that the US trade deficit had reached a record level in 2005, having increased by 18 per cent in that year and being fuelled by rising

${ }^{37}$ General Accounting Office (GAO), 'International Trade: Intensifying Free Trade Negotiating Agenda Calls for Better Allocation of Staff and Resources', report to Congressional Requesters, January 2004.

${ }^{38}$ US Senate, Committee on Finance, transcript, 'The Administration's International Trade Agenda, Hearing Before the Committee on Finance of the United States Senate', 108th Congress, second session, 9 March 2004.

${ }^{39}$ Interviews, members of Congress, representatives of business associations and representatives of labour unions. 
Chinese imports, sharpened still further the political sensitivity of the trade agenda. ${ }^{40}$ Much (but not all) of this sensitivity is related to the pronounced concern about the impact of trade on the US labour market. It is striking in this respect that, in a revealing survey of US public opinion and foreign policy conducted in 2004, the foreign policy goal that was considered most important by the US public was protecting the jobs of American workers (78 per cent), above preventing the spread of nuclear weapons (73 per cent) and combating international terrorism (71 per cent). ${ }^{41}$ Coupled with perceptions or fears of unfair trade practices, notably dumping, and threats from freer trade to domestic producers and manufacturers, the result has been a pronounced and widespread decline in enthusiasm for existing and new trade agreements, particularly among small industries, certain agricultural sectors such as tomatoes and sugar producers, the textiles sector and many services sectors. The primary upshot has been growing calls among such groups for a much more stringent application of US trade laws and opposition to the negotiation of new bilateral and regional agreements. ${ }^{42}$ These have been matched by congressional initiatives to strengthen the enforcement of existing trade agreements, Senator Max Baucus (D-Montana) calling in March 2004 for a thorough review by what was then known as the General Accounting Office (GAO) of current enforcement practices in response to such concerns as software piracy in India and the lax enforcement of intellectual property rights. ${ }^{43}$

In this sense, the legislative politics and public opinion surrounding these issues do not appear to have been altered in any fundamental way by an invocation of the importance of trade for national

${ }^{40}$ For commentaries see, for example, Vikas Bajaj, 'U.S. Trade Deficit Hit AllTime High in 2005', New York Times, 10 February 2006, and 'Trade Picture', Economic Policy Institute, 10 February 2006, available at http://www.epinet.org/content.cfm/ webfeatures_econindicators_tradepict20060210

${ }^{41}$ Chicago Council on Foreign Relations, Global Views 2004: American Public Opinion and Foreign Policy, Chicago, Chicago Council on Foreign Relations, 2004. According to these data, only 25 per cent of the US public considered NAFTA to be good for job security for American workers, and 42 per cent considered NAFTA to be good for the US economy. Conversely, 69 per cent considered NAFTA to be good for the Mexican economy and an equal number deemed it good for job creation in Mexico.

${ }^{42}$ Interviews, representatives of the National Association of Manufacturers and representatives of various congressional offices.

${ }^{43}$ US Senate, Committee on Finance, transcript, 'The Administration's International Trade Agenda'. 
security. What the above discussion tells us most of all, however, is that it is not national security concerns that dictate either the substance of trade strategies or their political reception. The fact that early agreements such as those with Chile, Singapore, Morocco or Australia passed through Congress with relative ease is not because of any direct relevance to broader foreign policy concerns, but rather because they represented little threat to labour and key sectors in the US economy. It must also be stressed again that, in each of these agreements, 'sensitive' sectors and products were excluded from negotiation. Those agreements that represent a considerably greater threat - notably CAFTA, which was eventually passed in the House of Representatives by only the narrowest margin of 217 votes to 215 are subject to the same partisan and public battles as those that surrounded similarly contentious agreements in the past, such as the NAFTA. If there is a 'pattern' that prevails in US foreign economic policy, then, it is explained in important part by the degree of perceived economic 'threat', particularly to the labour market. Under the first Bush administration, early trade strategies prioritized negotiations that could be concluded and ratified relatively quickly, and this was facilitated by the fact that none of the countries concerned represented excessive threats to US labour and/or the most politically sensitive parts of the US economy. Neither the substance of the strategies, nor the political environment that surrounded their articulation, nor the processes by which they were formulated and implemented are illuminated in any demonstrable way by a notion of securitization. Nevertheless, the dynamics of linkage between economic and security strategies remain, as ever, a pivotal dimension of an explanation of the evolution of US foreign economic policy.

\section{'Patterns' of Trade Policy?}

The final point to raise in a critique of the securitization thesis relates to the question of whether there is a discernible 'pattern' in the selection of partners for trade negotiations. An explanation of trade and investment strategies that privileges 'security' or the war on terror as their primary determinant is considerably weakened when put to the empirical test. Unquestionably, a tight link between the global war on terror and economic and trade strategies can be discerned in the engagement of the USA in key regions and with 
key strategic partners. The Middle Eastern and Mediterranean regions are the clearest instances of the use of bilateral trade negotiations as mechanisms for pursuing a range of security and political objectives. Unequivocally, the USTR has framed these trade talks as a strategy of embracing modernizing, reforming countries (such as Morocco) and encouraging the political transformations that are central to the Bush administration's global vision. As Zoellick put it, for instance, 'piece by piece, the administration is building a mosaic of modernizers with a plan that offers trade and openness as tools for Muslim leaders looking toward the rebirth of an optimistic and tolerant Islam'. ${ }^{44}$ The hearing before the Senate Committee on Finance in March 2004 on economic and trade policy in the Middle East endorsed such propositions wholeheartedly as responding, as Senator John McCain (R-Arizona) put it, to the need to 'encourage such long overdue political, economic, and social changes in the Arab world'. ${ }^{45}$

The other dimension that is often highlighted by proponents of a securitization thesis - the conditioning of trade negotiations on support for US foreign policy objectives - is also evident. Senator Max Baucus, for example, observed in his opening statement to the same Senate hearing that "[a programme of trade preferences] would give the President the power to allow Middle Eastern countries that meet certain conditions, such as supporting the war on terrorism and reforming their economies, to export products that the President approves duty-free' ${ }^{46}$ The element of 'reward' for support in the war on terror was also central to the free trade agreement with Australia. Zoellick's refusal to negotiate a similar agreement with New Zealand in the same vein has been clearly linked with the more critical position of Prime Minister Helen Clark's government over the Iraq war and differences, ongoing since 1984, over the refusal to allow US nuclear-powered or nuclear-armed ships to dock in New Zealand

${ }^{44}$ Robert B. Zoellick, 'When Trade Leads to Tolerance', New York Times, 6 December 2004.

${ }^{45}$ US Senate, Committee on Finance, transcript, 'U.S. Economic and Trade Policy in the Middle East, Hearing before the Committee on Finance of the United States Senate', 108th Congress, second session, 10 March 2004; also interviews, representatives of the Office of the USTR and members of key congressional committees.

${ }^{46}$ US Senate, Committee on Finance, transcript, 'U.S. Economic and Trade Policy in the Middle East'. 
ports. ${ }^{47}$ (The possibility of an agreement was, however, revived by Zoellick's successor as USTR, Rob Portman, in 2005.)

The renewed interest in Asia-Pacific, and especially in South-East Asia, is also an important result of the increased strategic importance of the region for the war on terror. Singapore - a case frequently used to bolster observations of securitization - is certainly of strategic importance to the USA for the use of facilities in Singapore by the US military and cooperation between the armed forces of each country. ${ }^{48}$ The attempts to negotiate an agreement with ASEAN countries also demonstrate a close linkage of this sort, as do the range of bilateral arrangements with individual countries, the delaying tactics that have been used with others (such as Chile) as a result of their lack of support for US foreign policy actions, and renewed US interest in the potential of APEC to contribute to the elaboration of the antiterrorism agenda.

Yet the argument can only be pushed so far. While it is very clear that some of the trade negotiations that the USA has opened and some of the economic deals that it has struck have been motivated by raw strategic considerations associated with anti-terrorism and broader foreign policy goals, there is no sufficiently visible pattern in this respect which could sustain a general argument of this nature. Singapore, for example, it is not of demonstrably greater strategic significance to the USA than several other countries in the region. Moreover, as in the case of Chile, this was an agreement instigated not by the Bush administration but by the Clinton administration as part of an articulated strategy of establishing selected economies from each region as cornerstones of its global liberalization agenda. When one surveys the array of bilateral negotiations in which the USA has been involved since the start of the decade, one would be hard pressed to locate such agreements as that with Chile in such a framework, or indeed the CAFTA. Neither Chile nor any of the CAFTA countries is of the major security or military importance to the USA's overarching foreign policy that would, according to a securitization thesis, explain their prioritization. Equally, the idea

${ }^{47}$ I am grateful to one of the anonymous referees for prompting me on this point. For a thorough discussion of the nuclear issue in New Zealand-USA relations, as well as a broader overview of the bilateral relationship, see Bruce Vaughn, 'New Zealand: Background and Bilateral Relations with the United States', CRC Report for Congress, Congressional Research Service, Library of Congress, 16 June 2005.

${ }^{48}$ Desker, 'In Defence of FTAs', p. 19. 
that the US government has used bilateral negotiations to reward participation in its so-called 'coalition of the willing' finds only partial substantiation inasmuch as it is difficult to trace any consistent connection between the war on terror and patterns of foreign economic policy on which to construct a general argument, notwithstanding the instances outlined above.

\section{'AD HOC REACTIVISM'}

Under these circumstances, it is significant that analysts and participants in the policy process have struggled to determine how and why certain countries are selected for bilateral trade and investment negotiations. Indeed, the above arguments are reinforced by the fact that the apparently ad hoc nature of foreign economic strategies has caused widespread (and widely documented) comment, including in the Washington political arena itself. The USTR has been pressed continually by such congressional committees as House Ways and Means and Senate Finance to account for the manner in which it decides which trade negotiations to enter into, with frequently voiced reservations about whether the answers to those questions have ever been satisfactory. ${ }^{49}$ For this reason, the GAO was charged in mid-2003, at Senator Baucus's behest, with investigating and clarifying how the US government chooses its bilateral trade partners along with the resource implications of the inclination towards bilateral negotiations, leading to a report published in January $2004 .{ }^{50}$

The findings of this report, consistent with the explanations offered by trade policy makers themselves ${ }^{51}$ can be condensed into two principal observations. The first is that the selection of trade partners is not a mechanical exercise informed by systematic data, but rather one in which the USTR favours flexibility and discretion in identifying the factors that are relevant to the selection. Discussions surrounding the ways in which trade partners are selected gave rise

${ }^{49}$ Interviews, members of Congress and representatives of congressional committees.

50 GAO, 'International Trade'.

51 Interviews, representatives of the Office of the USTR and other agencies involved in the inter-agency process. 
eventually to a list of six criteria intended to guide the process. ${ }^{52}$ The GAO's assessment demonstrates clearly that each trade agreement has responded to different criteria, and a different mix of considerations, as highlighted earlier in the present discussion. In his written response to the GAO's report, Zoellick also observes that while there are concrete criteria that inform the selection process, these "can aid in the making of selections of FTA partners, but the execution of the strategy requires the careful judgment of policymakers in close consultation with Congress and private sector stakeholders'. ${ }^{53}$ The second is that, in the list of six criteria, the one factor that is common across the range of trade negotiations is that which the GAO termed 'country readiness' - namely, the necessary political will, trade capabilities and rule of law systems.$^{54}$ Notably too, the consideration of readiness usually follows the prior overture from the prospective trading partner. Most often, the list of six criteria guides the discussions once an expression of interest in negotiating with the USA has been received. It is rarely the case that the six criteria are deployed in discussions about partners for the USTR to 'target' actively for negotiations in the future; rather, the initial impetus is an external request for consideration. ${ }^{55}$

In this sense, US trade strategies are defined fundamentally by what Feinberg has called 'ad hoc reactivism'. In the current debate, the USTR and others have preferred the adjectives 'flexible' or 'not mechanical' to 'ad hoc', but the point remains that trade negotiations have been initiated 'generally in response to an insistent external request, not as the considered unfolding of a carefully designed internally-generated strategic plan'. ${ }^{56}$ In this light, and put together with the observations about the sprawling and fragmented bureaucratic process associated with trade, a securitization thesis about the nature of foreign economic policy assumes a degree of purposiveness

${ }^{52}$ In the GAO report, these are listed as country readiness, economic/commercial benefit, benefits to the broader trade liberalization strategy, compatibility with US interests, congressional/private sector support; US government resource constraints. In interviews, interestingly, most versions differed slightly from this list of six, but in their thrust departed only insubstantially.

${ }^{53}$ GAO, 'International Trade', pp. 57-63.

${ }^{54}$ Ibid., p. 9.

${ }^{55}$ Interviews, Office of the USTR and other state agencies involved in trade policy.

${ }^{56}$ Feinberg, 'The Political Economy of United States' Free Trade Arrangements', p. 1022. 
and proactiveness which simply is not, and has never been, characteristic of US economic and trade policy-making processes. Furthermore, the foreign economic policy process exhibits a fundamental degree of continuity in this respect, which again challenges the propositions of newness and disruption to normal rules and practices posited by a securitization thesis. A few examples to illustrate this continuity will suffice. It is well known that the NAFTA was primarily the result of Mexican pressure for the expansion of the Canada-USA bilateral relationship. The forerunners of the FTAA were indeed US initiatives, but their conversion into a concrete FTAA negotiation process was the result of sustained pressure from Latin American and Caribbean (and Canadian) governments, and indeed was marked by considerable reticence and disinterest on the part of the US government in the mid-1990s. The Chilean agreement was the result of nearly a decade of banging on the door by Chilean officials once the idea of NAFTA accession had been dropped by the Clinton administration. APEC was an initiative propelled by Japan and Australia. And, as noted, the USA has been consistently behind the bilateral curve, responding largely to the activities of economic rivals and partners rather than driving a consistent strategic agenda in any sort of systematic way.

\section{COMMERCIAL AND ECONOMIC INTERESTS}

Within this context of reactivism, there is a range of interests that shape the particular trade strategies that emerge. One set of interests, as we have seen, relates to the broader security and foreign policyrelated goals of the US government, whether these refer to the linking of trade and investment in the Caribbean with drug control strategies, for example, or to the proposal of a MEFTA in order to foster democratization in the Middle East. An equally important set of interests is specifically economic and commercial in nature. Their significance is, however, easily underestimated if one focuses too closely on the nature and distribution of US commercial interests as the determinants of trade strategies. Indeed, over the 1990s and into the present decade, most of the countries with which it has opened bilateral negotiations have been of only modest importance in the overall structure of US trade. The same can be said of the major regional initiative of the FTAA, the USA having only slight 
commercial interests in much of South America and particularly the Southern Cone ${ }^{57}$ In addition, generally speaking, countries in the Americas, South-East Asia and other regions encounter far greater and more diverse barriers to the US market than those encountered by US exports to those countries, given the widespread processes of trade and investment liberalization that occurred across the developing world over the 1980s and 1990s. Tariff and non-tariff barriers to the US market are also highest and most intractable in sectors that are of particular importance to a wide range of its trading partners, such as agriculture, steel and textiles.

Consequently, in most of its contemporary trade negotiations, neither market access to the economies of trading partners nor trade in goods has been foremost in the interests of the USA. There is undoubtedly a range of key commercial priorities that inform these trade strategies, among which the continued prevalence of tariff barriers to the export of manufactured goods (particularly salient in the Central American and Australian agreements) and the expansion of trade in services are most salient. But the far more important set of interests shaping trade strategies clusters around wider concerns with issues of trade-related disciplines and the various facets of the so-called 'new trade agenda'. These include, notably, issues such as investment, intellectual property, government procurement, competition policy, environmental protection and labour issues. Regional and bilateral avenues are central to the USTR's drive to entrench these broader economic disciplines inasmuch as they offer significant opportunities for propelling this agenda forwards at a time when the multilateral process has slowed to the point of virtual paralysis, and when these have been precisely the issues around which the major conflicts with developing countries have turned.

The trade agenda, in a nutshell, is not only about trade. Rather, US trade interests are dictated in the main by the prospects of establishing binding agreements across a range of other economic policy areas. These are 'trade-related' inasmuch as trading arrangements necessitate, politically as well as economically, attention to a plethora of other policies. But these connections are secondary in importance to the point that trade is the mechanism by which the US government has chosen to pursue its priorities in these other areas. This is clear in

${ }^{57}$ For details, see Nicola Phillips, 'The Americas', in Anthony Payne (ed.), The New Regional Politics of Development, Basingstoke, Palgrave, 2004, pp. 29-58.

( $)$ The Author 2007. Journal compilation @ 2007 Government and Opposition Ltd 
the ways in which regional and bilateral trade agreements have consistently been articulated as 'single undertakings': market access and trade benefits come only with agreements on investment, government procurement, competition policy, intellectual property rights and so on. One of the USTR's stipulations for undertaking trade negotiations is explicitly the clear understanding that the agreement will be comprehensive, evidence of which is also gleaned from observation of potential partners' track records in WTO negotiations ${ }^{58}$ It is also explicit in the criteria developed to guide the selection of trading partners and outlined in the GAO report and elsewhere. The GAO report highlights the twin considerations of the economic and commercial benefit to the USA and the degree to which a negotiation will assist in the broader trade liberalization strategy, the latter relating to 'the prospective FTA partner's overall support for U.S. trade goals' ${ }^{59}$ More generally, however, considerable emphasis is laid by trade policy makers on the contributions that a trade agreement will make to economic reform in the partner country, whether in the broad terms of comprehensive liberalization (as in some Middle Eastern cases) or in particular policy areas. ${ }^{60}$

This emphasis on economic reform and the enforcement of 'trade-related' economic disciplines is evident across the debates about the benefits of particular trade negotiations as well as in the substance of the trade agreements themselves. To take very briefly the example of the Chile-USA agreement: aside from its commercial provisions, the agreement called forth a number of fundamental changes to Chilean economic policies and legal frameworks. The Chilean government committed itself to such measures as the elimination of a range of drawback and duty referral programmes and its 85 per cent 'auto luxury tax', and to putting in place the regulatory systems necessary for the enforcement of the US meat inspection system. Moreover, the agreement carried provisions limiting Chilean governments' future ability to impose controls on capital flows - a system of controls on the precipitous exit of capital having been a long-standing feature of the Chilean development strategy. These provisions represented a crucial dimension of the strategies to mould

${ }^{58}$ Interviews, Office of the USTR.

${ }^{59}$ GAO, 'International Trade', p. 10.

${ }^{60}$ Interviews, Office of the USTR; also see US Senate, Committee on Finance, transcript, 'The Administration's International Trade Agenda', among many other sources, for various expressions of this emphasis. 
the investment environment in a manner consistent with the interests of US investors, despite an emerging consensus among respected liberal economists on the utility of such measures. In Jagdish Bhagwati and Daniel Tarullo's words, for instance, a ban on capital controls represents 'bad financial policy, bad trade policy, and bad foreign policy, and constitute a bad trade-off for increased trade and investment flows' ${ }^{61}$ Both the Chile-USA and Singapore-USA agreements were also heralded as 'the first FTAs anywhere in the world to have specific, concrete obligations to enhance transparency and efficiency of customs procedures' ${ }^{62}$ which went along with extensive provisions relating to regulation in such areas of key interest in the US trade agenda as intellectual property, telecommunications and electronic commerce.

The evolution of US foreign economic policy, then, reflects in essence a political response to the political difficulties encountered in realizing the USTR's particular agenda in the multilateral arena, and the prioritization of bilateralism corresponds similarly to parallel difficulties in regional negotiations. In other words, the logic propelling a more robust pursuit of bilateral arrangements rests on the apparently greater utility of bilateralism in serving key US negotiating priorities and in serving the broader agenda of economic reform. Without exception, the bilateral agreements that trade officials in Washington refer to as 'state of the art' trade deals have been 'comprehensive' and have conformed with a WTO-plus template - that is, they seek to exceed existing multilateral provisions in all of the key disciplines of interest in the US trade agenda. Notably, the WTO-plus format is not universal in its application, inasmuch as the USA has excluded from the remit of the negotiations the areas of trade remedies and agricultural subsidies and, as noted, sensitive sectors and products have routinely been 'carved out' of bilateral and regional agreements. The other point about the bilateral negotiations in which the USA has been involved is that they have invariably been characterized by profound asymmetries in bargaining power, and

${ }^{61}$ Financial Times, 17 March 2003; also congressional testimonies in US House of Representatives, Committee on Financial Services, transcript, 'Opening Trade in Financial Services - The Chile and Singapore Examples, Hearing Before the Subcommittee on Domestic and International Monetary Policy, Trade and Technology of the Committee on Financial Services', 1 April 2003.

${ }^{62}$ Statement of Regina K. Vargo, Assistant USTR for the Americas, before the Senate Committee on the Judiciary, 14 July 2003.

(C) The Author 2007. Journal compilation @ 2007 Government and Opposition Ltd 
very frequently have been with partners that are significantly (or in some cases almost entirely) dependent on the US market. Consequently, the political logistics of reaching agreements on distinctively US terms are significantly eased. Finally, bilateralism offered a way of enhancing the momentum of the 'competition in liberalization' process. One of the clear considerations in the calculations of the benefits of a particular negotiation for the broader trade liberalization agenda has been the extent to which it would contribute both to subsequent negotiations and, moreover, to the incentives for other countries to enter into similar negotiations with the USA.

\section{COMPETITION FOR REGIONAL LEADERSHIP}

The final dimension of an explanation of the evolution of US foreign economic strategies relates to the circumvention of competitive regional leadership aspirations, especially in Asia-Pacific (with Japan and China) and the Americas (with Brazil). In both regions, this political dynamic has been pivotal not only in shaping the key regional projects, but also in lending momentum to the bilateral thrust of US trade strategies. The relevant points about the Americas and the USA-Brazil relationship have been made earlier and do not require further elaboration here, save to highlight that the strategy of 'isolating' Brazil, by negotiating around it, has been effective in drawing many of the countries of the Americas into a regional agenda dominated by the imprint of US preferences and interests, contrary to the challenges to such an arrangement that had been articulated consistently by Brazilian governments.

In Asia-Pacific, the element of competition for regional leadership is of longer standing, and evident both in the evolution of APEC and East Asian regionalism and in the narrower relationships between Japan and the USA and China and the USA. US interest in APEC was initially dictated by the fear that the Australian-Japanese initiative would lead to the exclusion of the USA from a new regional order in a strategically crucial part of the world. Diverting an entrenchment of Japanese leadership and the management of Chinese power in the region were crucial reasons for the active attempts on the part of the US government to insert the USA firmly into the APEC process. The subsequent competition between the USA and Japan for leadership of the Asia-Pacific initiative was pivotal to the disappointing 
momentum that the APEC process achieved for most of the 1990s, the consistent attempts mutually to 'block' the initiatives and interests of the other country being crucial to the resulting 'under-supply of regional collective goods'. ${ }^{63}$ The political problems associated with the pursuit of the USA's hegemonic strategies in Asia-Pacific were compounded by the impact of the Asian financial crises of the late 1990s.

Bilateral strategies have also been a strategic response to the processes by which key regional competitors have sought systematically to negotiate trade and investment agreements both regionally among themselves and with extra-regional partners. Consequently, as noted, the concern in the agencies of the US government and state has been that such developments threaten its economic position as preferential trading and investment relationships proliferate across the world. In this latter sense, there is a clear recognition in trade policy-making circles that 'each one [of these trade agreements] sets rules and opens markets for those that have signed on and creates hurdles for those outside the agreement ${ }^{64}{ }^{64}$ Equally, one of the core spurs to US activity in the Americas has been the agendas pursued by the EU in opening negotiations with key countries such as Chile and Mexico, as well as with the Mercosur (the customs union in the Southern Cone of Latin America). Conversely, aggressive bilateral and extra-regional negotiations by Chile and Mexico themselves, especially with Asian partners, have reinforced US inclinations to engage in similar strategies in order to retain its economic and strategic positions in global and regional arenas. The plethora of bilateral arrangements in AsiaPacific has had exactly the same sort of impact. It is worth noting, for example, that US negotiations with Singapore were initiated while Japan was working on a similar free trade agreement with that country, and the exclusion of the USA in new bilateral and regional arrangements in ASEAN also constituted a significant impetus to the Enterprise for ASEAN Initiative.

Most of all, the evolution of foreign economic policy in these two regions represents a core dimension of the global and regional hegemonic projects of the USA. Developments in regionalist projects and

${ }^{63}$ David P. Rapkin, 'The United States, Japan, and the Power to Block: The APEC and AMF Cases', Pacific Review, 14: 3 (2001), p. 376; also John Ravenhill, APEC and the Construction of Pacific Rim Regionalism, Cambridge, Cambridge University Press, 2001.

${ }^{64}$ Zoellick, 'Falling Behind on Free Trade'. 
in the distribution of economic power in the global political economy have generated a perception of a weakening hegemonic foothold, in the sense of an ability both to set the agenda that frames these projects and to prevail over regional rivals for dominance within them. It has systematically been stated, particularly in the Defense Department's Quadrennial Defense Reviews, that the Bush administration's Asia-Pacific policy is explicitly about consolidating US dominance and hegemony in the region, and doing so in a way that prevents the emergence of a significant threat from Japan, China or any other 'competitor'. ${ }^{65}$ (Such a strategy of preventing the emergence of economic or military rivals was also articulated towards the end of the George H. W. Bush administration and, not surprisingly, associated with the figures who served in both governments.) In this sense, the prioritization of bilateral trade negotiations with a range of partners across the Americas and Asia-Pacific has been explicitly a strategy of either (as in Asia-Pacific) competing effectively with rival regional or global leaders or (as in the Americas) isolating the opposition mounted to the entrenchment of distinctively US visions of regionalist projects and US dominance of regional political economies.

\section{CONCLUSION}

The framework offered by the concept of securitization, as originally developed by Buzan et al., has become particularly popular in the post-9/11 world. It is not, of course, intended to be of peculiar relevance to this period, but the inclinations of the George W. Bush administration, coupled with events during his period in office, have been seen to imbue it with an especial relevance. Its pertinence to the evolution of, for example, migration and immigration policies in various settings has been particularly striking. Yet I have sought to argue that its application to the sphere of foreign economic policy finds only rather tenuous foundations. I have suggested that this line of thought is problematic not for its observation of a tight linkage between foreign economic and security agendas, but rather for its concomitant suggestions (a) that this is significantly new, (b) that

${ }^{65}$ US Department of Defense, Quadrennial Defense Review Report 2001, Washington, DC, 30 September 2001, e.g. p. 4; also 2006 report. 
there has been a rupture of the 'normal rules and practices' of policy-making and implementation in the area of trade and foreign economic policy, and (c) that securitization provides an adequate framework for understanding foreign economic policy in its design, substance and implementation.

This argument suggests that the economic-security nexus in the contemporary period is considerably more complex than is often suggested by analyses influenced by the contexts of $9 / 11$, the neoconservative movement in US politics and the renewed attempts to militarize the global engagement of the USA. The security imperative, while undeniably exercising a hold over the political agenda in the USA, has not been invoked sufficiently effectively to alter the panoply of domestic political and bureaucratic characteristics that traditionally have undermined the coherence and cohesiveness of US foreign economic strategies. The domestic politics of trade debate have long been, and remain, influenced far more by concerns relating to the US labour market and the threat of competition to domestic producers than by any invocation of a link between security and economic priorities. Equally, the particular political and bureaucratic characteristics of the trade and foreign economic policy-making process have militated against the absorption of this policy area into that dominated by the agencies of the US state most closely related to security policy, and particularly against any significant changes in the 'normal rules and practices' of foreign economic policy-making. Finally, alongside the domestic constraints on processes of 'securitization', the manner in which US strategies are moulded and, indeed, limited by global and regional politics are clearly in evidence in the processes we have been concerned with here. This article has attempted to set out an argument highlighting the limits of the securitization thesis as a means of understanding, much less theorizing, the nature of US foreign economic policy in the contemporary world. It suggests the need to return to a long-running theoretical debate surrounding the economic-security nexus in the hegemonic project of the United States, across different issue areas, and to think much more carefully about the nature and politics of US power in the contemporary period. 